\title{
Public sector financial management and democracy quality: The role of the accounting systems
}

\author{
Marco Bisogno ${ }^{\text {a }}$, Beatriz Cuadrado-Ballesteros ${ }^{b}$ \\ a)Dipartimento di Scienze Aziendali - Management \& Innovation Systems, Via Giovanni Paolo II, Fisciano, Salerno (Italy). \\ b) Department of Administration and Business Economics, Multidisciplinary Institute for Enterprise (IME), Campus Miguel Unamuno, Salamanca (Spain).
}

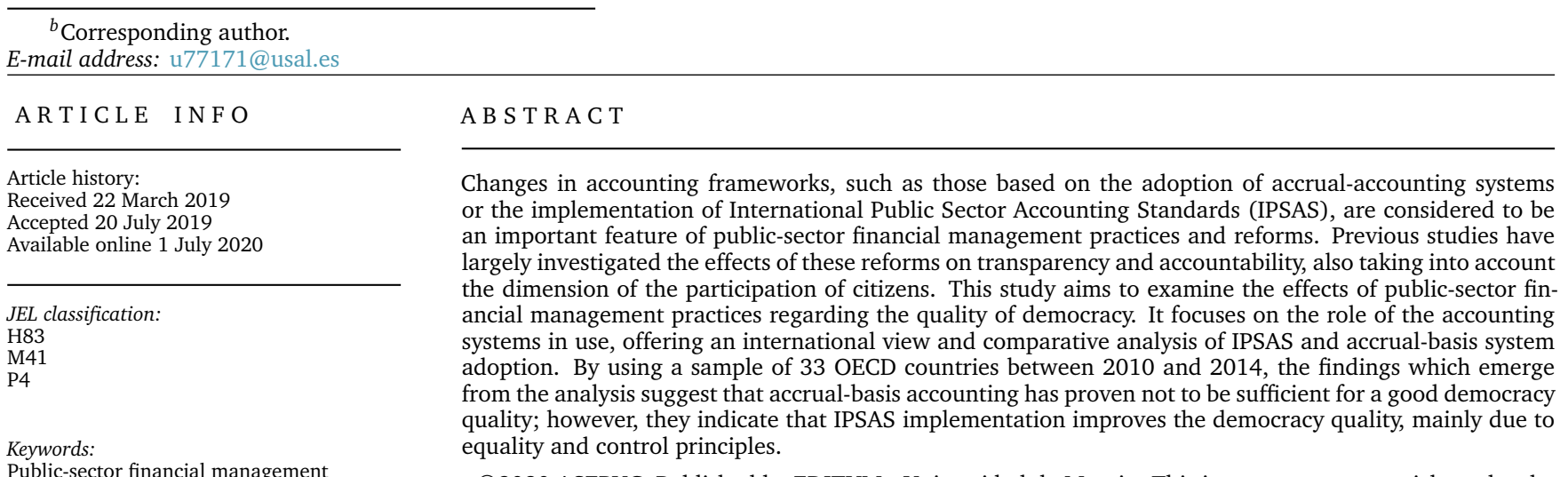

Public-sector financial management Democracy

Public sector accounting

IPSAS

Transparency CC BY-NC-ND license (http://creativecommons.org/licenses/by-nc-nd/4.0/).

Gestión financiera del sector público y calidad de la democracia: el papel de los sistemas contables

\author{
RES U M EN
}

\section{Códigos JEL:}

$\mathrm{H} 83$

M41

P4

Palabras clave:

Gestión financiera del sector público Democracia

Contabilidad del sector público

IPSAS

Transparencia
Los cambios en los marcos contables, como la adopción de sistemas contables basados en el devengo (accrual accounting) o la implementación de las Normas Internacionales de Contabilidad del Sector Público (International Public Sector Financial Accounting Standards, IPSAS), se consideran importantes reformas de la gestión financiera del sector público. Estudios anteriores han investigado en gran medida los efectos de estas reformas sobre la transparencia y la rendición de cuentas, teniendo en cuenta también el nivel de participación de los ciudadanos del sector público. Este estudio tiene como objetivo examinar los efectos de estas prácticas de gestión financiera sobre la calidad de la democracia. Concretamente, se centra en estudiar el papel de los sistemas de contabilidad a nivel internacional y ofrece un análisis comparativo de la adopción de las IPSAS y del sistema basado en los accruals. Utilizando una muestra de 33 países de la OCDE entre los años 2010 y 2014, los resultados sugieren que el uso de un sistema contable basado en los accruals no ha sido suficiente para mejorar la calidad de democracia; sin embargo, los hallazgos indican que la implementación de las IPSAS sí consigue mejorar la calidad de la democracia, principalmente debido a los principios de igualdad y control.

(C)2020 ASEPUC. Publicado por EDITUM - Universidad de Murcia. Este es un artículo Open Access bajo la licencia CC BY-NC-ND (http://creativecommons.org/licenses/by-nc-nd/4.0/). 


\section{Introduction}

This study aims to investigate the effects regarding the quality of democracy of public-sector financial management reforms, implemented in many countries at a central government level. Taking into account that transparency and accountability are deemed to be two key tenets of the quality of democracy (Warren, 2014), the motivation behind this research is twofold. On the one hand, it is stimulated by the growing need of increasing transparency of public-sector entities, in order to improve accountability toward citizens and stakeholders in general, enhancing also good governance and democratic participation (IMF, 2018). On the other hand, to be transparent, public-sector entities have to provide high quality information, allowing stakeholders to assess how public resources have been used.

This last aspect suggests focusing, among public-sector financial management practices and reforms, on the role of public-sector accounting, considering that key information is primarily obtained from the accounting system. Indeed, the adoption of accrual accounting is considered to be an important factor of public administration reforms globally (OECD, 2017). Scholars have frequently associated it with the New Public Management (NPM) principles (Biondi, 2014) and the implementation of the International Public Sector Accounting Standards (IPSAS). Previous studies have largely debated the impact of accrual accounting and the IPSAS implementation on transparency and accountability, even though several doubts have been raised, considering the specificities of the public sector (Blöndal, 2003; Barton, 2009). However, the possible link with the quality of democracy seems to be underinvestigated. This paper tries to fill this gap by using the Democracy Barometer index to represent democracy quality (Bühlmann et al., 2012).

The core message of this study is when dealing with public-sector financial management and accounting practices/reforms means not only addressing technical issues: these practices and reforms can lead to organizational changes, technological developments, and the adoption of new managerial approaches, also affecting the economic and political life of social communities (Mussari, 2014). Furthermore, they can allow citizens and stakeholders in general to be more aware of how resources are managed to deliver public services. Accordingly, adopting a wider approach rather than focusing on technicalities could prove to be useful in assessing the effects of public-sector financial management practices and reforms on a key aspect: the democracy quality.

From a methodological perspective, a sample of 33 OECD (Organisation for Economic Co-operation and Development) countries has been selected. The OECD context is highly appropriate considering that a large number of central governments have adopted accrual accounting, and, although IPSAS adoption is low, many standard-setters use them as a primary reference for elaborating their national standards (OECD/IFAC, 2017). The analysis spans the period 20102014 since the relevance of IPSAS implementation and accrual accounting has increased especially in the last years.

The empirical results suggest that accrual-basis accounting has proven not be enough for good democracy quality; the increase in the degree of IPSAS implementation results in a positive effect on the democracy principles headed by equality and control. Considering that IPSAS have attracted the attention of scholars, policymakers, standard-setters and practitioners over the world, our findings offer an international view and comparative analysis of IPSAS and accrual- basis system adoption. These findings enhance the relevance of the international harmonization of accounting standards beyond the accrual-basis systems in the public sector.

The remainder of the paper is structured as follows. Section 2 describes the quality of democracy, reviews the previous literature on IPSAS and accrual accounting in the public sector, and discusses the relationship between these two concepts. Section 3 describes the sample, variables and model of analysis. Section 4 presents and discusses the results, while Section 5 concludes, also providing suggestions for future research.

\section{Quality of democracy, accrual accounting and IPSAS implementation}

\subsection{Describing the concept of democracy quality}

Traditionally the quality of democracy has been understood beyond the participation of citizens in electing their representative elites. This so-called "minimal" definition applies to the political system, leading governments to be divided into democracy vs. dictatorship. However, the quality of democracy is a more complex phenomenon that applies to a wider conception of citizen participation.

The first approach to conceptualize this phenomenon was made by Dahl (1971), who supported an ideal concept of democracy called "polyarchy", which complies with freedom of association, expression and vote, political competition, diversity of information sources, impartial elections, and institutions that ensure governmental policies comply with voters' wishes. From this approach, several definitions of the quality of democracy have been provided, including specific features, such as the capacity of a society to take part in a democracy (Altman \& Pérez-Liñán, 2002), the control of political power (O'Donnell, 2004), and the level of welfare and equality (Diamond \& Morlino, 2004).

From this heterogeneity of definitions, a wide range of measures appears (Dahl, 1971; Altman \& Pérez-Liñán, 2002; Inglehart, 2003). The most popular democracy indices currently are Freedom House, Polity, and the Vanhanen Index, but they suffer from significant weaknesses in terms of conceptualization, measurement, and aggregation (Munck \& Verkuilen, 2002). Accordingly, Democracy Barometer has developed a new tool to measure the quality of democracy (called DQ), which tries to overcome the shortcomings of previous indicators.

DQ is obtained after a deep theoretical discussion on the different components that represent the quality of democracy, which refers to the balance between the values of freedom and equality, and the control that is required for such a balance. It is a middle-range approach: more than minimalist, because it adds the control dimension, but lesser than maximalist, because it does not consider the results of democratic systems (Bühlmann et al., 2012).

This study adopts DQ definition, which is based on three principles: freedom, equality, and control. Freedom refers to the protection of individual rights under a good rule of law, as well as the freedom of opinion and association (Beetham, 2004). Equality refers to the equal participation in the political process for all citizens and the equal representation of the preferences of all citizens, as well as the transparency of the political process (Dahl, 1998). Control is necessary to get a balance between freedom and equality, and ensuring citizens' representatives are accountable; coherently, it deals with the mutual constraints of constitutional powers, competitive elections, and government capability (Bühlmann et al., 2012). 
Table 1

Components of Democracy Barometer Index (DB)

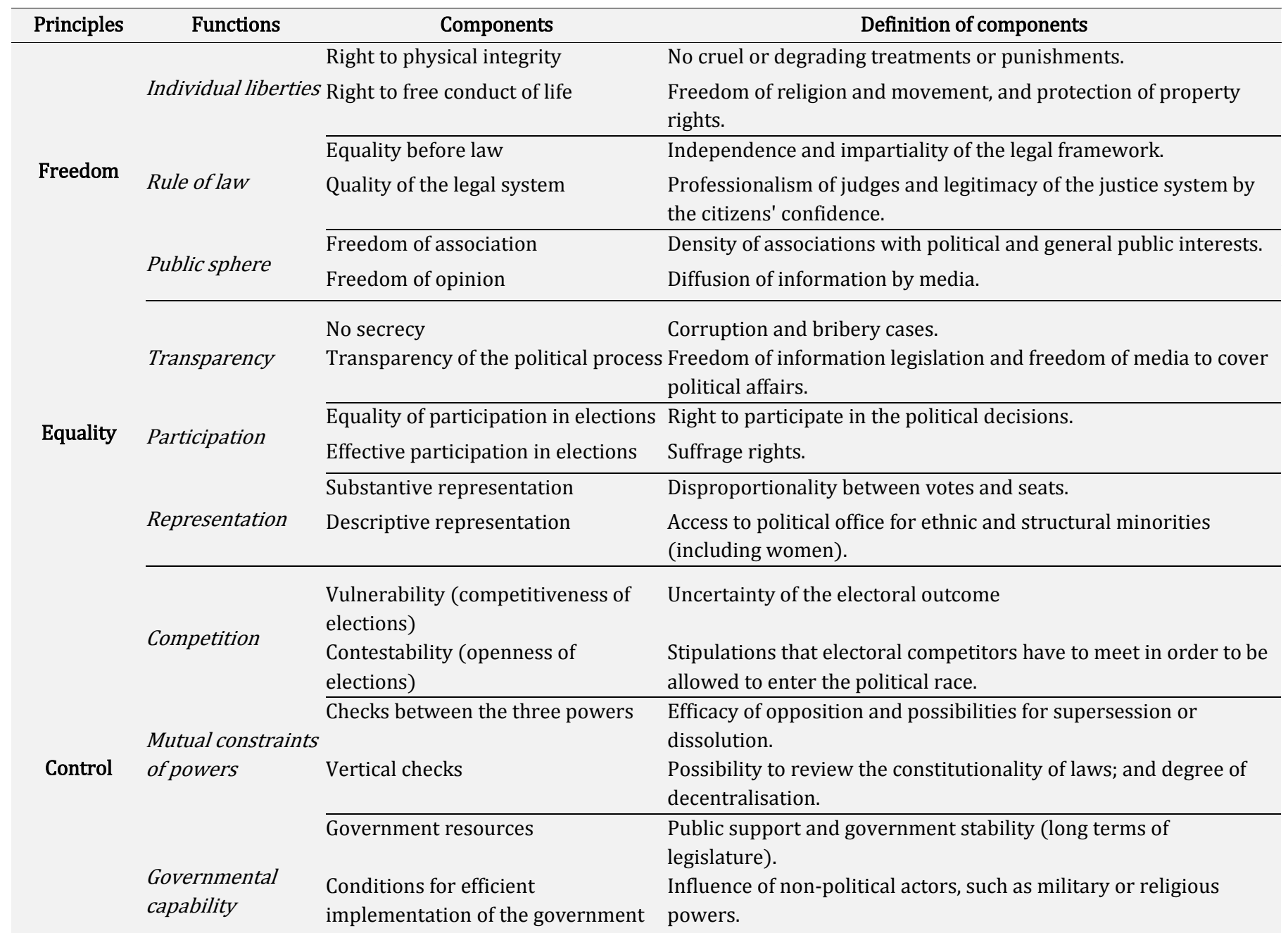

Source: The authors, based on Bühlmann et al. (2012)

Each of the three DQ principles is composed of three functions, which, in turn, consist of two components (see Table 1).

\subsection{The role of public financial management in enhancing democratic participation}

In the last decades, several countries have introduced important reforms, with the main aim being to improve efficiency and effectiveness of public-sector entities. The origin of the NPM movement was based on severe criticisms raised against the inefficiencies of public-sector organisations. Therefore, several ideas, tools and techniques derived from the private sector (such as decentralisation, management by objectives, competition, and so on), have been gradually introduced in the public-sector context (Hood, 1991; 1995). According to OECD (1995), a number of developed countries were guided towards the same reforms, to enhance performance management, to introduce more competition into the public sector, and to improve the quality of services available to citizens. Even though this approach was criticised, as it did not take into consideration appropriately several specificities of the public sector (Tagesson, 2015), it became the fil rouge underlining this wide reform movement, based on two fundamental dimensions: (i) output legitimacy, which includes the quality, effectiveness and efficiency of task fulfilment; (ii) input legitimacy, which describes the dimension of the participation of citizens (Kuhlmann and Woolmann, 2014, p. 42).

Citizens participation can be considered as one of the main relevant public governance principles (Bovaird \& Loffler, 2003) and it is heavily dependent on the information the government provides to citizens regarding how public resources are managed (Da Cruz et al., 2016). Politicians are expected to use money prudently, complying with public purposes, so accountability is necessary to ensure public officials do not abuse the power they wield on citizens' behalf (Behn, 2001). In this respect, many public administrations are investing increasing resources in information and communication technologies (ICT) so as to bring public entities and citizens closer to each other (EC, 2016; Cohen et al., 2017). Furthermore, scholars have pointed out the positive effects of e-government initiatives on the active participation of citizens (Aversano \& Manes-Rossi, 2017), documenting an improved accessibility of accounting information.

In this respect, it has been maintained that one of the key pillars of public-sector financial management practices concerns the accounting system in use, as reforms implemented under the NPM umbrella affect accounting, budgeting and reporting (Bergmann, 2009; Caperchione, 2006). Pollitt and Bouckaert (2017, p. 41) have pointed out that adopting new managerial approaches would imply, among other aspects, 
introducing new accounting frameworks. Therefore, in order to improve the quality of information, a widespread shift from cash-based systems to accrual-based systems has been observed, associating it with the advantages of the NPM principles (Biondi, 2014; Biondi \& Soverchia, 2014). Although there is a risk of considering accrual accounting systems mainly from a mere technical perspective, it has been claimed (Caruana et al., 2019, p. 3) that accounting frameworks are not designated only for financial reporting. They also refer to the legislation of the country in which they are applied, aiming at consolidating good governance practices, also enabling management accounting, financial management, budgeting, and performance management. In a similar vein, implementing International Public Sector Accounting Standards (IPSAS) is not a mere technical decision, as these standards and the related accounting framework are expected to improve the comparability of information (Wang, 2002), playing a key role for international harmonization (Benito et al., 2007). However, it might be critically observed that accrual accounting adoption and IPSAS implementation, while guaranteeing better-quality information (Sutcliffe, 2003), do not automatically improve accountability, which requires the active participation of citizens.

Accordingly, the higher the transparency, the better the accountability can be perceived as an effort to guarantee that government processes and actions are publicly accessible and considered by citizens as representing the appearance of democracy (Harrison \& Sayogo, 2014, p. 513). Therefore, it can be reasonably assumed that improving information quality fosters the participation of citizens, and hence it should enhance the quality of democracy. More specifically, it can be argued that if accrual accounting systems and IPSAS implementation, as key pillars of financial management practices, enhance transparency/accountability, they also improve the quality of democracy, because accountability plays an essential role in a "good" democracy quality (PapenfuSS \& Schaefer, 2010; Warren, 2014); it makes public what is done and who does it.

Accordingly, the following hypotheses are formulated:

\section{H1, Accrual accounting adoption affects the quality of democracy.}

\section{H2, IPSAS implementation affects the quality of} democracy.

\section{Research methodology}

\subsection{Sample}

To empirically test the proposed hypotheses, we need both a proxy for the quality of democracy and some public sector accounting indicators. The former has been obtained from the Democracy Barometer website, which provides data for 72 countries from 1990 to 2014. We have selected a sample of 33 OECD countries ${ }^{1}$ : Australia, Austria, Belgium, Canada, Chile, Czech Republic, Denmark, Estonia, Finland, France, Germany, Greece, Hungary, Iceland, Ireland, Israel, Italy, Japan, Luxembourg, Mexico, Netherlands, New Zealand, Norway, Poland, Portugal, Slovak Republic, Slovenia, Spain, Sweden, Switzerland, Turkey, the UK, and the USA.

The data regarding IPSAS and accrual accounting reforms was hand-collected from: (i) the International Federation of

\footnotetext{
${ }^{1}$ South Korea and Latvia were excluded from the sample, since there is no information on democracy quality for the former, and there are scarce data on some control variables for Latvia.
}

Accountants (IFAC) website, which obtains information both from member organisations and publicly available sources listed in each jurisdiction profile; and (ii) OECD/IFAC (2017), which is based on information gathered from a survey sent to the Ministries of Finance and equivalent bodies of all OECD countries. Considering that hand-collected data is not easily obtainable, the largest period over which it was possible to attain information on public-sector accounting status (concretely 2010-2014) was selected. Furthermore, this period is appropriate because of the relevance of accrual accounting and IPSAS has increased particularly in recent years.

The data on democracy quality was obtained from the Democracy Barometer website; and the remaining data was obtained from the World Bank dataset. All variables will be described below.

\subsection{Dependent variable}

The proxy selected to depict democracy quality is the index $D Q$, obtained from the Democracy Barometer website. It is represented by three principles, namely Freedom, Equality and Control, which are proxied by three functions that, in turn, consist of two components (see Table 1). We test the effect of public sector accounting on $D Q$ and the three principles (Freedom, Equality and Control) separately, because the impact may be different for each of them. We may expect accrual accounting and IPSAS adoption impact on Equality (i.e. transparency, participation, and representation) and Control (i.e. competition, mutual constraint of powers, and governmental capability); however, there are some doubts on their effect on Freedom (i.e. individual liberties, rule of law, and public sphere).

All these indicators take values between 0 and 100 (from the worst to the best quality) after a standardization process. Standardization is a very important process for the accuracy of the measures. To carry out this task, the Democracy Barometer project select a set of so-called "blueprint" countries that are established democracies, relying on previous indices of democracy (Polity and Freedom House). Then, the lowest and the highest values within such established democracies were rescaled to 0 and 100, respectively.

Once all indicators have the same scale, aggregation is possible. Aggregation of each level up to the 18 components are based on arithmetic means; while, the aggregation of the components to each function, functions to each principle, and the three principles to DQ is based on the optimal balance, i.e. by applying an formula that rewards high values at the lower levels and penalizes incongruences between pairs of values (Bühlmann et al., 2012).

\subsection{Independent variables}

Independent variables represent the status of public-sector account reforms (IPSAS and accrual-basis system implemented in order to elaborate and present the financial statements ${ }^{2}$ ) in each central government. As a matter of fact, there is a great diversity among countries (Benito et al., 2007; Roje et al., 2010). Several governments are piloting the implementation and leading a process to convergence towards IPSAS and accrual-basis accounting; others are in an initial stage, discussing the pros and cons of IPSAS implementation and still using cash-basis accounting, while others do not plan to adopt the international standards (Oulasvirta, 2014). Therefore, a variable that represents the diversity of implementation is required. Following previous studies

\footnotetext{
${ }^{2}$ The basis used for the budget is not considering here.
} 
(PwC, 2014; Christiaens et al., 2015; Bellanca \& Vandernoot, 2014; Cuadrado-Ballesteros et al., 2019), we have created two variables: IPSAS and Accruals. The former represents different levels of IPSAS adoption:

- IPSAS = 1: No actions have been undertaken to adopt IPSAS until now.

- IPSAS = 2: IPSAS are being adopted, i.e. the legislative process has been undertaken and/or IPSAS are partially applied.

- IPSAS = 3: IPSAS are adopted or national standards are/can be considered broadly consistent with IPSAS.

Similarly, the variable Accruals refers to the status of accruals reform(s) on the central government accounting system and it takes also three values:

- Accruals = 1: Public sector accounting standards are cash-basis.

- Accruals $=2$ : Public sector accounting standards are in transition to accrual accounting, or standards required modified accrual or modified cash systems.

- Accruals $=3$ : Public sector accounting standards are accrual-basis.

Accordingly, the value 1 to 3 was assigned to each country, in each year, regarding the standards (IPSAS) and accounting system (Accruals) used. Therefore, a country may result in different values over the sample period (2010-2014) if its status changes during the said period. The data was hand-collected from two sources: (i) the accounting system has been codified through the report OECD/IFAC (2017), which is based on information gathered from a survey sent to Ministries of Finance and equivalent bodies of all OECD countries; and (ii) the level of IPSAS implementation has been obtained from the IFAC website, which collects the information from member organizations and publicly available sources listed in each jurisdiction profile. More specifically, the IFAC triangulates various sources within and outside the jurisdiction, such as relevant organizations (e.g. institutes of auditors and accountants, financial supervisory authorities, accountants' regulatory boards, and so on), legislation, and publications of international organizations (e.g. Deloitte, World Bank, European Commission, and so on).

\subsection{Control variables}

The results are controlled by the following determinants of democracy quality (Vanhanen, 2003; Li \& Reuveny, 2009; Teorell, 2010):

- Economic development is represented by the GNIpc (gross national income per capita).

- Socio-economic characteristics of population are represented by: Population, that is the number of inhabitants; Ethnic frac is the probability that two randomly selected citizens from a given country will not share a certain characteristic; and Education, expressed as a percentage of adults between 25 to 64 years of age who attended (upper) secondary-schools.

- Market liberalization is represented by Eco_globalization, i.e. the KOF economic globalization index that has values between 0 and 100 , where higher values indicate a higher degree of globalization.
- Political ideology of the government is controlled by a dummy variable that has the value 1 for the left-wing parties and 0 otherwise (namely, Ideology).

The data were collected from different official sources, namely the OECD National Accounts data, the World Bank national accounts data, and the Quality of Government Basic Dataset (Dahlberg et al., 2017).

\subsection{Model and technique of analysis}

To test the hypotheses of this study, we propose the following model that will be empirically estimated by using the Stata 13 software:

$$
\begin{aligned}
\text { Democracy }_{\text {it }}= & \beta_{0}+\boldsymbol{\beta}_{1} \text { Accounting }_{\text {it }}+\beta_{2} \text { GNIpc }_{i t} \\
& +\beta_{3} \text { Population }_{i t}+\beta_{4} \text { Ethnic frac }_{i t} \\
& +\beta_{5} \text { Education }_{i t}+\beta_{6} \text { Eco globalization }_{i t} \\
& +\beta_{7} \text { Ideology }_{i t}+\sum_{j=8}^{12} \beta_{j} \text { Year }_{t}+\eta_{i}+v_{i t}
\end{aligned}
$$

Sub-indexes i and t refer to country and year, respectively; Democracy refers to democracy quality indicators, i.e. $D Q$, Freedom, Equality and Control; Accounting refers to IPSAS and Accruals variables; the remaining variables are those control variables previously mentioned; and $\mathrm{Year}_{t}$ are $\mathrm{j}$ dummy variables that have the value 1 in year $t$ and 0 otherwise. The error term $\eta_{i}$ refers to unobservable heterogeneity, which reprsents the characteristics of each country, which are different from other countries, but are invariant over time; while $v_{i t}$ is the classical disturbance term.

For panel data, the fixed- or random-effects (FE or RE) estimators could be used to estimate parameters $\beta$ of model 1 . However, the two estimators require homoscedastic and no serial correlated errors, and independent/control variables should be strictly exogenous. Hence, we test firstly these conditions by using the Breusch-Pagan test and the Wooldridge test, respectively. The p-values obtained are lower than 0.05 , which means that we must reject the null hypothesis of: (i) homoscedastic errors; and (ii) no serially correlated errors. Then, neither FE nor RE estimators are appropriate in this case.

Second, endogeneity problems also appear in model 1 due to three reasons (Wooldridge, 2010): (i) the use of proxy variables to represent the difficulty to quantify concepts (e.g. IPSAS/Accruals reforms, or democracy quality); (ii) results could be additionally controlled by other variables (e.g. inflation, wage gap, GINI index, foreign direct investment, economic freedom, rural population, etc.), but they have been omitted due to multicollinearity problems; and (iii) reverse causality between some control variables and the dependent variables ${ }^{3}$.

Accordingly, endogeneity should be addressed, by using instrumental variable (IV) methods. In the presence of heteroscedasticity, the conventional IV estimator is consistent but inefficient (Baum et al., 2003). Therefore, it is necessary to use another one, such as the dynamic panel estimator (Arellano \& Bond, 1991) that overcomes such a limitation. More concretely, here we use the two-step system estimator of Arellano

\footnotetext{
${ }^{3}$ GNI, Education, and Economic globalization affect the level of democracy (as it is showed in the model), but also democracy may affect the level of GNI (Heo \& Tan, 2001), Education (Glaeser et al., 2007) and Economic globalization (Li \& Reuveny, 2003). These causal relationships introduce endogeneity in the model.
} 
and Bover (1995), which augments the traditional estimator, called two-step difference estimator (Arellano \& Bond, 1991). The difference estimator is consistent as the sample size is long, but it has poor small sample properties, and the system estimator is able to solve this problem (Arellano \& Bover, 1995).

The system estimator is derived from a "system" of two equations, the "level" equation that is the model (1), and the "first-difference" equation, which is denoted as follows:

$$
\begin{aligned}
\Delta \text { Democracy }_{\text {it }} & =\beta_{0}+\boldsymbol{\beta}_{1} \Delta \text { Accounting }_{\text {it }}+\beta_{2} \Delta \text { GNIpc }_{i t} \\
& +\beta_{3} \Delta \text { Population }_{i t}+\beta_{4} \Delta \text { Ethnic frac }_{i t} \\
& +\beta_{5} \Delta \text { Education }_{i t}+\beta_{6} \Delta \text { Eco globalization }_{i t} \\
& +\beta_{7} \Delta \text { Ideology }_{i t}+\sum_{j=8}^{12} \beta_{j} \Delta \text { Year }_{t}+\eta_{i}+v_{i t}
\end{aligned}
$$

The system estimator uses the lagged values of the righthand-side variables included in the model as instruments. For equation (2), the instruments are lagged values of endogenous and predetermined variables, and for equation (1) the instruments are the first differences of the endogenous and predetermined variables ${ }^{4}$. This estimator uses endogenous and predetermined variables as instruments to remove the endogeneity, instead of outside instruments such as the traditional IV estimators. While it is difficult to prove that outside instruments are uncorrelated with the error term and, at the same time, contain enough information on those endogenous variables, it is demonstrated that lagged values are natural instruments that contain information on the current value of the endogenous variables; additionally, they are uncorrelated with the error term (Arellano \& Bond, 1991). Therefore, the system estimator uses more instruments than the traditional IV estimators, which improves efficiency.

However, the number of instruments should not be very high in relation to the number of observations because the results could be biased. The most adequate instruments are the closest lags since the furthest cannot contain information on the current value of the variables. The closest lags in the system estimator are $\mathrm{t}-1$ and $\mathrm{t}$ for endogenous and predetermined variables (Pindado \& Requejo, 2015). Accordingly, instrument validity is tested by two tests: (i) ArellanoBond test for AR(2) in first differences, under the null hypothesis of no serial correlation between the error terms; and (ii) Hansen test of over-identification restrictions, under the null hypothesis that the over-identifying restrictions are valid. Tables of results show the p-values of the two tests.

\section{Results}

\subsection{Descriptive analysis}

Table 2 illustrates the descriptive statistics of all variables entered into the model 1 . Firstly, the mean values of the four democracy quality indicators are around 57 and 58 on a scale from 0 to 100 . This means that, in general, the level of democracy quality of our sample countries is medium, and there is still work to be done to improve it. Nevertheless, there are relevant differences in the sample; Turkey and

\footnotetext{
${ }^{4}$ The two-step system estimator allows including time-invariant variables. Roodman (2009) noted that asymptotically, this does not affect the coefficient estimates for other regressors because all instruments for the equation in levels are assumed to be orthogonal to fixed effects, indeed to all time-invariant variables.
}

Denmark show the minimum and the maximum $D Q$ values (29.78 and 72.73). Turkey also shows the lowest values of the three principles, Freedom (18.53), Equality (30.97) and Control (37.88); while the best value of Freedom is showed by Denmark (82.), Iceland in the case of Equality (75.34) and

\begin{tabular}{|c|c|c|c|c|c|}
\hline Variable & Obs & Mean & Std. Dev. & Min & Max \\
\hline$D Q$ & 165 & 57.6621 & 8.5902 & 29.7828 & 72.7310 \\
\hline Freedom & 165 & 58.3197 & 13.4753 & 18.5297 & 82.5852 \\
\hline Equality & 165 & 57.1023 & 8.9792 & 30.9688 & 75.3408 \\
\hline Control & 165 & 57.6541 & 7.6735 & 37.8833 & 75.0707 \\
\hline IPSAS & 165 & 1.6484 & 0.8021 & 1 & 3 \\
\hline Accruals & 165 & 2.3273 & 0.8422 & 1 & 3 \\
\hline$\overline{G N I p c}$ & 165 & 37.1489 & 12.3609 & 14.9787 & 58.0759 \\
\hline Population & 154 & 37.4991 & 60.6685 & 0.3180 & 318.8570 \\
\hline Ethnic_frac & 165 & 0.2473 & 0.1888 & 0.0119 & 0.7124 \\
\hline Education & 153 & 43.5176 & 14.0058 & 16.4723 & 75.1777 \\
\hline Eco_globalization & 132 & 77.0277 & 10.7415 & 45.2283 & 95.2746 \\
\hline Ideology & 165 & 0.2606 & 0.4403 & 0 & 1 \\
\hline \multicolumn{6}{|c|}{ IPSAS and Accruals variables distribution } \\
\hline \multirow[t]{4}{*}{ IPSAS } & & Freq. & & Percent & Cum. \\
\hline & 1 & 92 & & 55.76 & 55.76 \\
\hline & 2 & 39 & & 23.64 & 79.39 \\
\hline & 3 & 34 & & 20.61 & 100 \\
\hline \multirow[t]{4}{*}{ Accruals } & & Freq. & & Percent & Cum. \\
\hline & 1 & 40 & & 24.24 & 24.24 \\
\hline & 2 & 31 & & 18.79 & 43.03 \\
\hline & 3 & 94 & & 56.97 & 100 \\
\hline
\end{tabular}
Switzerland stands out in the Control principle (75.07).

Table 2

Descriptive statistics

Secondly, the mean value of IPSAS is 1.65 in a range between 1 and 3 , revealing that the full adoption of IPSAS in the OECD context is not very high. In our sample, Australia, Canada, Estonia, New Zealand, Switzerland, and the UK have the value IPSAS $=3$, as figure 1 shows. However, the mean value of the Accruals is 2.33, in a range between 1 and 3. This may point out that, although IPSAS are not so common in the OECD countries, they tend to use accrual-basis systems in public sector accounting to a greater extent, as recently noted by OECD/IFAC (2017). Concretely, 17 countries show the value Accruals $=3$, as shown in figure 1 . This situation can also be seen at the bottom of table 2 (although only $20.61 \%$ of observations has the value 3 for the IPSAS variable, almost $57 \%$ use accrual-basis accounting).

Table 2 also shows the descriptive statistics of control variables. The mean value of the GNIpc is 37,148.9 US\$, although there are relevant differences among countries. Regarding ethnic diversity, Canada and Japan show the most (0.7124) and the least (0.0119) fragmented population, respectively. Regarding adult literacy, $43.52 \%$ of $25-64$ yearsof age had attended (upper) secondary school, on average. The mean value of the KOF index (Eco_globalization) suggests a high level of globalization (77.03). Finally, the mean value of Ideology variable indicates that $26 \%$ of observations has left-wing governments in office.

Table 3 shows the bivariate correlations between variables entered into model 1 . High correlations between $D Q$ and its three principles (Freedom, Equality, and Control) are noted. The coefficient between IPSAS and Accruals is also relevant, owing to the two variables representing the extent of the accounting maturity; so, the model 1 is estimated by intro- 
Figure 1

Distribution of IPSAS and Accruals variables by country

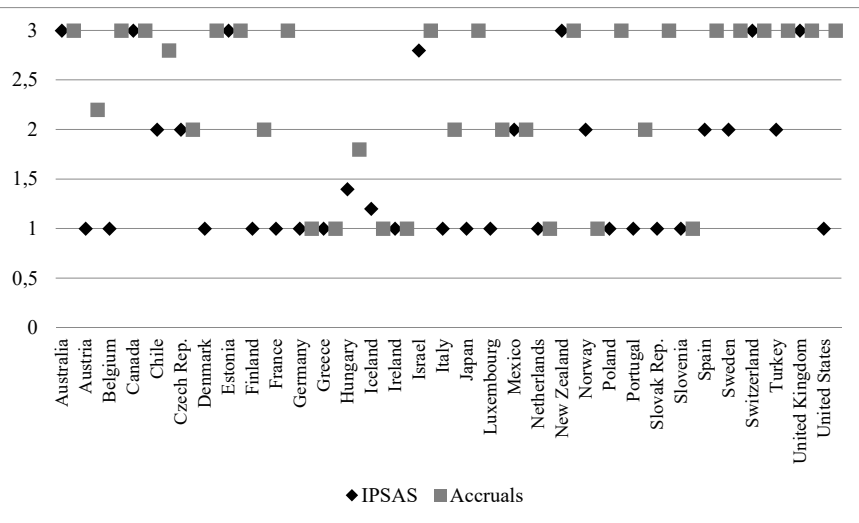

IPSAS $=1$ no actions have been undertaken to adopt IPSAS; IPSAs $=2$ IPSAS are being adopted or are partially applied; IPSAS $=3$ IPSAS are adopted or national standards are/can be considered broadly consistent with them; Accruals $=1$ cash-basis accounting; Accruals $=2$ modified accrual or modified cash accounting systems; Accruals $=3$ accrual-basis accounting.

ducing these variables separately. However, although they are similar, they are not totally equivalent: Accruals variable refers to accrual-basis accounting (both national standards and IPSAS); and IPSAS variable refers to IPSAS implementation (both cash- and accrual-basis). Therefore, it is interesting to test the effect of both the proxies on the democracy quality. Regarding control variables, in general, they are weakly correlated; most of the correlation coefficients are less than 0.3, which is the accepted threshold for multicollinearity problems (Wooldridge, 2010).

Table 3

Bivariate correlations

\begin{tabular}{lllllll}
\hline & $D Q$ & Freedom & Equality & Control & IPSAS & Accruals \\
\hline DQ & 1 & & & & & \\
Freedom & $0.9038^{* * *}$ & 1 & & & & \\
Equality & $0.882^{* * *}$ & $0.6961^{* * *}$ & 1 & & & \\
Control & $0.7371^{* * *}$ & $0.462^{* * *}$ & $0.5676^{* * *}$ & 1 & & \\
IPSAS & -0.0112 & $-0.1286 \dagger$ & 0.0127 & $0.1737^{*}$ & 1 & \\
Accruals & $-0.1355 \dagger$ & $-0.1826^{*}$ & -0.1165 & 0.0026 & $0.4419^{* * *}$ & 1 \\
GNIpc & $0.6817^{* * *}$ & $0.6599^{* * *}$ & $0.6226^{* * *}$ & $0.4013^{* * *}$ & 0.0956 & $-0.1627^{*}$ \\
Population & $-0.3412^{* * *}$ & $-0.2254^{* *}$ & $-0.3436^{* * *}$ & $-0.3359^{* * *}$ & $0.2716^{* * *}$ & $0.172^{*}$ \\
Ethnic_frac & -0.0911 & $-0.1554^{*}$ & $-0.1858^{*}$ & $0.1885^{*}$ & $0.3213^{* * *}$ & $0.1943^{*}$ \\
Education & $0.162^{*}$ & $0.2227^{* *}$ & 0.095 & 0.0374 & 0.0018 & 0.0964 \\
Eco_globalization & $0.4719^{* * *}$ & $0.4358^{* * *}$ & $0.4001^{* * *}$ & $0.3453^{* * *}$ & $-0.2656^{* *}$ & $-0.2636^{* *}$ \\
Ideology & $0.1616^{*}$ & 0.1296 & $0.1839^{*}$ & 0.0951 & -0.0683 & 0.0163 \\
\hline & GNIpc & Population & Ethnic_frac & Education & Eco_glob. & Ideology \\
\hline GNIpc & 1 & & & & & \\
Population & 0.0627 & 1 & & & & \\
Ethnic_frac & 0.0247 & $0.1877^{*}$ & 1 & & & \\
Education & 0.0231 & -0.1453 & -0.1394 & 1 & & \\
Eco_globalizat & $0.1489 \dagger$ & $-0.2829^{* * *}$ & 0.0554 & $0.2242^{*}$ & 1 & \\
Ideology & $0.247^{* *}$ & 0.0795 & -0.0489 & 0.074 & $0.1767^{*}$ & 1 \\
\hline
\end{tabular}

Notes: $\dagger,{ }^{*},{ }^{* *},{ }^{* * *}$ significant at $10,5,1$, and 0.1 percent level, respectively.

\subsection{Explanatory analysis}

Tables 4 and 5 illustrate the empirical results obtained by estimating model 1 with the two-step system estimator. The former shows the results for the global index $D Q$; and the latter shows the results for each of the three democracy quality principles (Freedom, Equality, and Control).

Focusing on table 4, a positive effect of IPSAS on the global level of democracy quality $(D Q)$ is recorded, and the coefficient is statistically relevant at $95 \%$ confidence level, suggesting that the democracy quality is positively related with IPSAS implementation. However, the link is negative in the case of Accruals, being statistically relevant also at 95\%. This result calls into question the benefits of accrual-basis accounting systems per se in terms of democracy quality.

Regarding the economic development, GNIpc is positively related with $D Q$, being statistically relevant at $99.9 \%$ confidence level. Although the impact is very small, it suggests that the most economically developed OECD countries tend to show a higher level of democracy quality, according to the traditional thesis of Muller (1995). A negative and relevant impact of ethnic fractionalization on democracy quality is observed, being relevant at different levels. The impact of economic globalization on $D Q$ is also relevant and positive in the two equations, indicating that globalization positively affects democracy quality. Finally, political ideology impacts negatively on $D Q$, suggesting that democracy quality is lower in countries governed by left-wing parties.

\section{Table 4}

Link between public sector accounting and democracy quality

\begin{tabular}{lllll} 
& \multicolumn{2}{l}{ Test variable: IPSAS } & \multicolumn{2}{l}{ Test variable: Accruals } \\
& Coef. & Std. Err. & Coef. & Std. Err. \\
\hline IPSAS & $3.5243^{*}$ & 1.3034 & & \\
Accruals & & & $-1.8685^{*}$ & 0.6992 \\
GNIpc & $0.0004^{* * *}$ & 0.0001 & $0.0005^{* * *}$ & 0.0001 \\
Population & 0.0314 & 0.0335 & $0.0361^{*}$ & 0.0167 \\
Ethnic_frac & $-2.0960^{*}$ & 1.0175 & $-1.7094 \dagger$ & 0.8391 \\
Education & 0.0052 & 0.0695 & -0.0592 & 0.0476 \\
Eco_globalization & $0.5266^{* *}$ & 0.1646 & $0.5395^{* * *}$ & 0.0969 \\
Ideology & $-1.3348^{* *}$ & 0.4051 & $-1.1775^{* * *}$ & 0.2778 \\
Constant & 0.3571 & 12.3401 & 10.3242 & 6.5940 \\
\hline Arellano-Bond test for & \multirow{2}{*}{$\operatorname{Pr}>\mathrm{z}=0.694$} & $\operatorname{Pr}>\mathrm{z}=0.467$ \\
AR(2) & \multicolumn{3}{|l}{$\operatorname{Pr}>$ chi2 $=0.713$} \\
\hline Hansen test & $\operatorname{Pr}>$ chi2 $=0.998$ &
\end{tabular}

Notes: Dependent variable: DQ; All regressions include year fixed effects; $\uparrow,{ }^{*},{ }^{* *},{ }^{* * *}$ significant at 10, 5, 1, and 0.1 percent level, respectively.

Table 5 shows the results for the three principles of democracy quality: Freedom (panel A), Equality (panel B), and Control (panel C). The results are like those obtained for $D Q$, although the statistical relevance of IPSAS and Accruals is lost in the case of Freedom. Observing the functions and components of Freedom described in table 1, it can be argued that public accounting harmonization is not a determinant of such democracy principle, as expected. Nevertheless, we found relevant evidence in the case of Equality and Control functions.

\subsection{Robustness checking}

To test the robustness of previous findings, the variables IPSAS and Accruals have been changed to dIPSAS and dAccruals, which are dummy variables that take the value 1 if IPSAS and accrual-basis accounting have been implemented, respectively, and 0 otherwise. Therefore, the model (1) is estimated again, for DQ, Freedom, Equality and Control. The results are included in Table 6 , which shows only the coefficients for the main variables, to facilitate the reading ${ }^{5}$. They are consistent with those obtained previously, i.e. IPSAS adoption impacts positively on the global level of democracy quality $(D Q)$ and also on Equality and Control indicators. However, the effect is negative in the case of accrual-basis accounting systems. Furthermore, neither dIPSAS nor $d A c$ cruals are statistically relevant in explaining Freedom, such as previous findings have also suggested.

\footnotetext{
${ }^{5}$ The remaining results are available under request.
} 
Table 5

Link between public sector accounting and democracy quality principles

\begin{tabular}{|c|c|c|c|c|}
\hline \multicolumn{5}{|c|}{ Panel A. Freedom principle } \\
\hline & \multicolumn{2}{|c|}{ Test variable: IPSAS } & \multicolumn{2}{|c|}{ Test variable: Accruals } \\
\hline & Coef. & Std. Err. & Coef. & Std. Err. \\
\hline IPSAS & 0.5547 & 2.2002 & & \\
\hline Accruals & & & 0.2826 & 0.3953 \\
\hline GNIpc & $0.0004^{* *}$ & 0.0001 & $0.0005^{* * *}$ & 0.0001 \\
\hline Population & -0.0609 & 0.0458 & $-0.1139 *$ & 0.0477 \\
\hline Ethnic_frac & $-1.2437 \dagger$ & 0.6557 & 3.4275 & 8.7340 \\
\hline Education & -0.0344 & 0.0956 & $0.1203^{*}$ & 0.0514 \\
\hline Eco_globalization & $-0.2113 \dagger$ & 0.1210 & $-0.3892^{*}$ & 0.1551 \\
\hline Ideology & -0.1251 & 0.4294 & $-1.6396 \dagger$ & 0.8405 \\
\hline Constant & $6.7815^{* * *}$ & 0.8575 & $8.4256^{* * *}$ & 0.9440 \\
\hline Arellano-Bond test for $\mathrm{AR}(2)$ & \multicolumn{2}{|c|}{$\operatorname{Pr}>z=0.760$} & \multicolumn{2}{|c|}{$\operatorname{Pr}>z=0.889$} \\
\hline Hansen test & \multicolumn{2}{|c|}{$\operatorname{Pr}>\operatorname{chi} 2=1.000$} & \multicolumn{2}{|c|}{$\operatorname{Pr}>\operatorname{chi} 2=1.000$} \\
\hline \multicolumn{5}{|c|}{ Panel B. Equality principle } \\
\hline & \multicolumn{2}{|c|}{ Test variable: IPSAS } & \multicolumn{2}{|c|}{ Test variable: Accruals } \\
\hline & Coef. & Std. Err. & Coef. & Std. Err. \\
\hline IPSAS & $5.7929 * * *$ & 1.5429 & & \\
\hline Accruals & & & $-3.1688^{* *}$ & 0.9264 \\
\hline GNIpc & $0.0006^{* * *}$ & 0.0001 & $0.0005^{* * *}$ & 0.0001 \\
\hline Population & -0.0256 & 0.0189 & 0.0208 & 0.0309 \\
\hline Ethnic_frac & $-2.2450^{* * *}$ & 0.4603 & $-2.0057 \dagger$ & 1.0792 \\
\hline Education & -0.0370 & 0.0633 & 0.0204 & 0.0562 \\
\hline Eco_globalization & $0.2909^{* *}$ & 0.0985 & $0.4509^{*}$ & 0.1759 \\
\hline Ideology & -0.3316 & 0.3616 & $-0.8456^{* * *}$ & 0.1924 \\
\hline Constant & 1.3861 & 0.8727 & 1.5729 & 1.1799 \\
\hline Arellano-Bond test for $\mathrm{AR}(2)$ & \multicolumn{2}{|c|}{$\operatorname{Pr}>z=0.967$} & \multicolumn{2}{|c|}{$\operatorname{Pr}>z=0.155$} \\
\hline Hansen test & \multicolumn{2}{|c|}{$\operatorname{Pr}>\operatorname{chi} 2=0.976$} & \multicolumn{2}{|c|}{$\operatorname{Pr}>\operatorname{chi} 2=0.802$} \\
\hline \multicolumn{5}{|c|}{ Panel C. Control principle } \\
\hline & \multicolumn{2}{|c|}{ Test variable: IPSAS } & \multicolumn{2}{|c|}{ Test variable: Accruals } \\
\hline & Coef. & Std. Err. & Coef. & Std. Err. \\
\hline IPSAS & $2.4215^{* * *}$ & 0.4176 & & \\
\hline Accruals & & & $-2.6205^{* *}$ & 0.8773 \\
\hline GNIpc & $0.0006^{* * *}$ & 0.0001 & $0.0007^{* * *}$ & 0.0001 \\
\hline Population & 0.0192 & 0.0264 & -0.0526 & 0.0382 \\
\hline Ethnic_frac & $-1.4552^{*}$ & 0.6003 & 6.1594 & 10.0263 \\
\hline Education & 0.0245 & 0.0924 & -0.0660 & 0.1052 \\
\hline Eco_globalization & $0.6678^{* * *}$ & 0.0928 & 0.1703 & 0.1808 \\
\hline Ideology & -0.4805 & 0.6431 & -0.6588 & 0.5844 \\
\hline Constant & -1.8268 & 0.8644 & $2.9702 \dagger$ & 1.5829 \\
\hline Arellano-Bond test for $\mathrm{AR}(2)$ & \multicolumn{2}{|c|}{$\operatorname{Pr}>\mathrm{z}=0.331$} & \multicolumn{2}{|c|}{$\operatorname{Pr}>z=0.616$} \\
\hline Hansen test & \multicolumn{2}{|c|}{$\operatorname{Pr}>\operatorname{chi} 2=0.999$} & \multicolumn{2}{|c|}{$\operatorname{Pr}>\operatorname{chi} 2=1.000$} \\
\hline
\end{tabular}

Notes: Dependent variables: Freedom, Equality, and Control, respectively; All regressions include year fixed effects; $\dagger,{ }^{*},{ }^{* *},{ }^{* * *}$ significant at $10,5,1$, and 0.1 percent level, respectively.

\section{Discussion and conclusions}

This study has examined changes in the accounting frameworks in the wide context of reforms implemented in many countries under the umbrella of NPM, aiming to bring finance and management together (Bergmann, 2009). These reforms do not only have important financial implications; they also affect accounting, budgeting and reporting (Caperchione, 2006).

Scholars have largely studied the benefits of changes in the accounting frameworks, through IPSAS implementation and/or accrual accounting adoption, in terms of transparency and accountability. This study adds new insights, making a relevant contribution to the public-sector financial management and accounting literature, as it considers a more complex concept, namely the democracy quality. In a context where being accountable is essential for increasing the quality of democracy (Warren, 2014), it is expected that governments should disclose comparable, reliable, and timely information. Therefore, this article has investigated the relationship between IPSAS implementation and accrual account-
Table 6

Robustness checking for IPSAS and Accruals variables.

\begin{tabular}{|c|c|c|c|}
\hline \multicolumn{4}{|c|}{ Panel A. DQ variable } \\
\hline & \multicolumn{2}{|c|}{ Test variable: IPSAS } & Test variable: Accruals \\
\hline & Coef. & Std. Err. & Std. Err. \\
\hline dIPSAS & $2.5309^{*}$ & 1.1873 & \\
\hline dAccruals & & & $-1.2097^{*} \quad 0.5665$ \\
\hline Arellano-Bond test for $\mathrm{AR}(2)$ & $\operatorname{Pr}>z=$ & 0.438 & $\operatorname{Pr}>z=0.819$ \\
\hline Hansen test & $\operatorname{Pr}>$ chi 2 & $=0.990$ & $\operatorname{Pr}>$ chi $2=0.989$ \\
\hline \multicolumn{4}{|c|}{ Panel B. Freedom principle } \\
\hline & \multicolumn{2}{|c|}{ Test variable: IPSAS } & Test variable: Accruals \\
\hline & Coef. & Std. Err. & Std. Err. \\
\hline dIPSAS & -1.2137 & 2.6510 & \\
\hline dAccruals & & & -0.8213 \\
\hline Arellano-Bond test for $\mathrm{AR}(2)$ & $\operatorname{Pr}>z=$ & 0.505 & $\operatorname{Pr}>z=0.552$ \\
\hline Hansen test & $\operatorname{Pr}>\operatorname{chi} 2$ & $=0.991$ & $\operatorname{Pr}>$ chi $2=0.992$ \\
\hline \multicolumn{4}{|c|}{ Panel C. Equality principle } \\
\hline & \multicolumn{2}{|c|}{ Test variable: IPSAS } & Test variable: Accruals \\
\hline & Coef. & Std. Err. & Std. Err. \\
\hline dIPSAS & $6.6562^{*}$ & 2.7328 & \\
\hline dAccruals & & & $-4.0461^{*}$ \\
\hline Arellano-Bond test for AR(2) & $\operatorname{Pr}>\mathrm{z}=$ & 0.762 & $\operatorname{Pr}>z=0.160$ \\
\hline Hansen test & $\operatorname{Pr}>$ chi 2 & $=0.956$ & $\operatorname{Pr}>\operatorname{chi} 2=0.614$ \\
\hline \multicolumn{4}{|c|}{ Panel D. Control principle } \\
\hline & \multicolumn{2}{|c|}{ Test variable: IPSAS } & Test variable: Accruals \\
\hline & Coef. & Std. Err. & Std. Err. \\
\hline$\overline{d I P S A S}$ & $2.6918^{*}$ & 1.3057 & \\
\hline dAccruals & & & $-3.7674 \dagger \quad 2.1667$ \\
\hline Arellano-Bond test for $\mathrm{AR}(2)$ & $\operatorname{Pr}>\mathrm{z}=$ & 0.571 & $\operatorname{Pr}>z=0.994$ \\
\hline Hansen test & $\operatorname{Pr}>\operatorname{chi} 2$ & $=0.981$ & $\operatorname{Pr}>$ chi $2=0.986$ \\
\hline
\end{tabular}

Notes: Dependent variables: DQ, Freedom, Equality, and Control, respectively; All regressions include year fixed effects; $\dagger,{ }^{*},{ }^{* *},{ }^{* * *}$ significant at $10,5,1$, and 0.1 percent level, respectively.

ing adoption, considered as key pillars of financial management practices, with the quality of democracy, illustrating the usefulness in modernizing public sector accounting to ensure comparability. As many countries are discussing IPSAS implementation, the experiences of previous "adopters" can serve as a learning process.

For a sample of 33 OECD countries in the period 20102014, empirical findings indicate that IPSAS adoption may improve democracy quality, probably due to harmonization of accounting standards which ensure internationally comparable information (Lapsley et al., 2009), enhancing accountability (Wang, 2002). Conversely, it can be argued that the empirical findings question the effect of accrual accounting per se on democracy quality, suggesting that the use of international standards may discharge accountability, stimulating democratic participation (PapenfuSS \& Schaefer, 2010; Warren, 2014) more than the accounting system in itself.

Considering that public sector accounting standards can be heavily influenced by private sector practices, Chan (2003) argued for a gradual symmetric approach to accruals; however, this study promotes the harmonization of public sector accounting rules, aiming at not only accountability, but also democracy quality.

This study also contributes to the recent literature on democracy quality, focused until now on developing reliable indicators (Altman \& Pérez-Liñán, 2002; Bühlmann et al., 2012; O'Donnell, 2004) and studying determinant factors (Vanhanen, 2003; Li \& Reuveny, 2009; Teorell, 2010). The findings which emerge from this research suggest that democracy quality is affected by other factors, such as accounting harmonization as a key aspect of public-sector financial management practices. Accordingly, dealing with financial management practices and reforms would imply considering 
not only the quality, effectiveness and efficiency of task fulfilment ("output legitimacy"), but also the dimension of the participation of citizens and the democratic control ("input legitimacy") (Kuhlmann \& Wollmann, 2014).

Despite these contributions, this study is not free of limitations. Firstly, IPSAS and accrual-basis reforms are difficult concepts to represent, because of the wide range of levels of implementation; the variables (IPSAS and Accruals) are proxies, so the results should be cautiously interpreted. In addition, the two public-sector accounting reforms are dynamic processes, so increasing the time period of analysis would improve the reliability of empirical findings. Here, a complete dataset with the available information has been created, but it would be interesting to improve these proxies in future research. Secondly, citizens would need to be aware of the accrual accounting and IPSAS implementation to effectively acquire an understanding of an increased comparability and standardization; however, this is not so easy to measure, and it is beyond the scope of this study.

For future research, it would be interesting to consider not only the IPSAS implementation, but also the specific case of EPSAS. In addition, it could be opportune to consider that some countries may be forced to implement IPSAS by the World Bank or the International Monetary Fund. Furthermore, enlarging the number of countries would allow control of the results by different areas (Anglo-Saxon, Latin American, Asian, etc.), due to the traditional orientations in accounting systems. Finally, it would be interesting to test the effect on the democracy quality of other variables related to different financial management practices and reforms.

\section{Funding}

This research did not receive any specific grant from funding agencies in the public, commercial or not-for-profit sectors.

\section{Conflict of interests}

The authors declare no conflict of interests.

\section{References}

Altman, D., \& Pérez-Liñán, A. (2002). Assessing the Quality of Democracy: Freedom, Competitiveness and Participation in Eighteen Latin American Countries. Democratization, 7, 85-100. https://doi.org/10.1080/714000256

Arellano, M., \& Bond, S. (1991). Some tests of specification for panel data: Monte Carlo evidence and an application to employment equations. Review of Economic Studies, 58, 277-297. https://doi.org/10.2307/2297968

Arellano, M., \& Bover, O. (1995). Another look at the instrumental variables estimation of error components models. Journal of Economics, 68, 29-51. https://doi.org/10.1016/ 0304-4076(94)01642-D

Aversano, N., \& Manes-Rossi, F. (2017). The democratic participation of local governments: A survey on Italian local governments web sites. In Cuadrado- Ballesteros, B. \& García-Sánchez, I.M. (Eds.), Local Governments in the Digital era: Looking for Accountability (pp. 55-72). New York: Nova Publisher. ISBN: 978-1-63485-891-5

Barton, A. (2009). The Use and Abuse of Accounting in the Public Sector Financial Management Reform Program in
Australia. Abacus, 45, 221-248. https://doi.org/10.1111/j. 1467-6281.2009.00283.x

Baum, C., Schaffer, M., \& Stillman, S. (2003). Instrumental variables and GMM: Estimation and testing. Stata Journal, 3, 1-31. https://doi.org/10.1177/ 1536867X0300300101

Beetham, D. (2004). Freedom as the Foundation. Journal of Democracy, 15, 61-75. https://doi.org/10.1353/jod.2004. 0057

Behn, R. D. (2001). Rethinking Democratic Accountability. Washington, DC: Brookings Institution Press. https://www. jstor.org/stable/10.7864/j.ctvdf03r8

Bellanca, S., \& Vandernoot, J. (2014). International Public Sector Accounting Standards (IPSAS) Implementation in the European Union (EU) Member States. Journal of Modern Accounting and Auditing, 10, 257-269. https://doi.org/ 10.17265/1548-6583/2014.03.001

Benito, B., Brusca, I., \& Montesinos, V. (2007). The harmonization of government financial information systems: The role of the IPSAS. International Review of Administrative Sciences, 73, 293-317. https://doi.org/10.1177/ 0020852307078424

Bergmann, A. (2009). Public Sector Financial Management. Essex, Prentice Hall - Pearson Education Limited. ISBN: 9780-273-71354-8

Biondi, Y. (2014). Harmonising European Public Sector Accounting Standards (EPSAS): Issues and perspectives for Europe's economy and society. Accounting, Economics, and Law: A Convivium, 4, 165-178. https://doi.org/10.1515/ ael-2017-0014

Biondi, Y., \& Soverchia, M. (2014). Accounting rules for the European Communities: A theoretical analysis. Accounting, Economics and Law, 4, 179-214. https://doi.org/10. 1515/ael-2013-0063

Blöndal, J. R. (2003). Accrual Accounting and Budgeting: Key Issues and Recent Developments. OECD Journal on Budgeting, 3, 43-131. https://doi.org/10.1787/16812336

Bovaird, T., \& Loffler, E. (2003). Evaluating the quality of public governance: indicators, models and methodologies. International Review of Administrative Sciences, 69, 313- 328. https://doi.org/10.1177/0020852303693002

Bühlmann, M., Merkel, W., Müller, L., \& WeSSels, B. (2012). The democracy barometer: a new instrument to measure the quality of democracy and its potential for comparative research. European Political Science, 11, 519-536. https://doi.org/10.1057/eps.2011.46

Caperchione, E. (2006). The New Public Management - a perspective for finance practitioners. Brussels, FEE. Available at: https://www. accountancyeurope.eu/wp-content/uploads/The/ New/ Public/ Management/ A/ Perspective/ for/ Finance/ Practitioners/_0612112200611033.pdf

Caruana, J., Brusca, I., Caperchione, E., Cohen, S., \& Manes-Rossi, F. (2019). Exploring the Relevance of Accounting Frameworks in the Pursuit of Financial Sustainability of Public Sector Entities: A Holistic Approach. In Caruana, J., Brusca, I., Caperchione, E., Cohen, S. and Manes-Rossi, F. (eds. by), Financial Sustainability of Public Sector Entities. The Relevance of Accounting Frameworks. Switzerland, Palgrave MacMillan (pp. 1-18). https://doi.org/10.1007/ 978-3-030-06037-4/ 1

Chan, J.L. (2003). Government accounting: an assessment of theory, purposes and standards. Public Money \& Management, 23, 13-20. https://doi.org/10.1111/1467-9302. 00336

Christiaens, J., Vanhee, C., Manes-Rossi, F., Aversano, N., 
\& Van Cauwenberge, P. (2015). The effect of IPSAS on reforming governmental financial reporting: an international comparison. International Review of Administrative Sciences, 81, 158-177. https://doi.org/10.1177/0020852314546580

Cohen, S., Mamakoua, X.J., \& Karatzimas, S. (2017). ITenhanced popular reports: Analyzing citizen preferences. Government Information Quarterly, 34, 283-295. https://doi. org/10.1016/j.giq.2017.04.003

Cuadrado-Ballesteros, B., Citro, F., \& Bisogno, M. (2019). The role of public-sector accounting in controlling corruption: an assessment of Organisation for Economic Co-operation and Development countries. International Review of Administrative Sciences, In press. https://doi.org/10.1177/ 0020852318819756

Da Cruz, N., Ferreira, T., Marques, A.F., Cunha, R., Susana, J., \& de Sousa, L. (2016). Measuring local government transparency. Public Management Review, 18, 866-893. https: //doi.org/10.1080/14719037.2015.1051572

Dahl, R. (1971). Polyarchy. New Haven: Yale University Press. ISBN: 9780300015652

Dahl, R.A. (1998). On democracy. New Haven: Yale University Press. ISBN: 9780300194463

Dahlberg, S., Holmberg, S., Rothstein, B., Khomenko, A., \& Svensson, R. (2017). The Quality of Government Basic Dataset, version Jan17. University of Gothenburg: The Quality of Government Institute, http://doi.org/10.18157/ QoGBasJan 17

Diamond, L., \& Morlino, L. (2004). The quality of democracy. An overview. Journal of Democracy, 15, 20-31. https: //doi.org/10.1353/jod.2004.0060

European Commision (EC). (2016). EU e-Government Action Plan 2016-2020: Accelerating the digital transformation of government. Available at: http://eur-lex.europa. eu/legal-content/EN/TXT/?uri=CELEX:52016DC0179 [Accessed at 13.3.2018].

Glaeser, E. L., Ponzetto, G. A., \& Shleifer, A. (2007). Why does democracy need education? Journal of Economic Growth, 12, 77-99. http://doi.org/10.1007/ s10887-007-9015-1

Harrison, T.M., \& Sayogo, S.D. (2014). Transparency, participation, and accountability practices in open government: A comparative study. Government Information Quarterly, 31, 513-525. https://doi.org/10.1016/j.giq.2014.08.002

Heo, U., \& Tan, A. C. (2001). Democracy and economic growth: A causal analysis. Comparative Politics, 33, 463-473. https://doi.org/10.2307/422444

Hood, C. (1991). A public management for all seasons. Public Administration, 69, 1, 3-19. https://doi.org/10.1111/ j.1467-9299.1991.tb00779.x

Hood, C. (1995). The 'New public management' in the 1980s - Variations on a Theme. Accounting, Organization and Society, 20, 93-109. https://doi.org/10.1016/ 0361-3682(93)E0001-W

IMF (2018). Fiscal Transparency Handbook. Washington, DC: International Monetary Fund. http://dx.doi.org/10. 5089/9781484331859.069

Inglehart, R. (2003). How Solid is Mass Support for Democracy? And How can we Measure it? Political Science \& Politics, 36, 51-57. https://doi.org/10.1017/ S1049096503001689

Kuhlmann, S., \& Wollmann, H. (2014). Introduction to Comparative Public Administration. Administrative Systems and Reforms in Europe. Cheltenham, Edward Elgar Publishing Limited. ISBN-13: 978-1783473595

Lapsley, I., R. Mussari, G., \& Paulsson, G. (2009). On the Adoption of Accrual Accounting in the Public Sec- tor: A Self-Evident and Problematic Reform. European Accounting Review, 18, 719-723. https://doi.org/10.1080/ 09638180903334960

Li, Q., \& Reuveny, R. (2003). Economic globalization and democracy: An empirical analysis. British Journal of Political Science, 33, 29-54. https://doi.org/10.1017/ S0007123403000024

Li, Q., \& Reuveny, R. (2009). Democracy and Economic Openness in an Interconnected System. New York: Cambridge University Press. https://doi.org/10.1017/ CBO9780511804953

Muller, E. N. (1995). Economic determinants of democracy. American Sociological Review, 60, 966-982. https: //doi.org/10.2307/2096435

Munck, G. L., \& Verkuilen, J. (2002). Conceptualizing and measuring democracy. Evaluating alternative indices. Comparative Political Studies, 35, 5-34. https://doi.org/10.1177/ 001041400203500101

Mussari, R. (2014). EPSAS and the Unification of Public Sector Accounting Across Europe. Accounting, Economics and Law: A Convivium, 4, 299-312. https://doi.org/10.1515/ ael-2014-0019

O'Donnell, G. A. (2004). Why the rule of law matters. Journal of Democracy, 15, 32-46. https://doi.org/10.1353/ jod.2004.0076

OECD (1995). Governance in transition: public management reforms in OECD countries, Paris, PUMA/OECD. ISBN13: $978-9264144866$

OECD/IFAC (2017). Accrual Practices and Reform Experiences in OECD Countries. Paris: OECD Publishing. https:// doi.org/10.1787/9789264270572-en [Accessed 30.6.2017].

Oulasvirta, L. (2014). The reluctance of a developed country to choose International Public Sector Accounting Standards of the IFAC. A critical case study. Critical Perspectives on Accounting, 25, 272-285. https://doi.org/10.1016/j.cpa. 2012.12.001

PapenfuSS, U., \& Schaefer, C. (2010). Improving public accountability by aligning reporting to organizational changes in public service provision. An empirical Internet study of all Austrian, German and Swiss towns and states from an agency-theory perspective. International Review of Administrative Sciences, 76, 555-576. https://doi.org/10.1177/ 0020852310372451

Pindado, J., \& Requejo, I. (2015). Panel data: A methodology for model specification and testing. In Wiley Encyclopedia of Management, Vol. 4, Finance. https://doi.org/10. 1002/9781118785317.weom040013

Pollit, C., \& Bouckaert, G. (2017). Public Management Reform. A Comparative Analysis - Into the Age of Austerity. Fourth edition, Oxford, Oxford University Press. ISBN-13: 978-0198795179

PwC, (2014). Collection of information related to the potential impact, including costs, of implementing accrual accounting in the public sector and technical analysis of the suitability of individual IPSAS standards - 2013/S 107-182395. Available at: http://ec.europa.eu/eurostat/documents/ 1015035/4261806/EPSAS-study-final-PwC-report.pdf

[Accessed 6.2.2018]

Roodman, D. (2009). How to do xtabond2: An introduction to difference and system GMM in Stata. The stata journal, 9(1), 86-136.

Roje, G., Vaiek, D., \& Vaiek, V. (2010). Accounting regulation and IPSAS implementation: Efforts of transition countries toward IPSAS compliance. Journal of Modern Accounting and Auditing, 6, 1-16. https://doi.org/10.17265/ 
$1548-6583 / 2010.12 .001$

Sutcliffe, P. (2003). The standards programme of IFAC's public sector committee. Public Money \& Management, 23, 29-36. https://doi.org/10.1111/1467-9302.00338

Tagesson, T. (2015). Accounting reforms, standard setting and compliance. In Budding, T., Grossi, G. and Tagesson, T. (eds by), Public Sector Accounting. London, Routdledge (pp. 8-22). https://doi.org/10.4324/9781315848389

Teorell, J. (2010). Determinants of democratization: Explaining regime change in the world, 1972-2006. Cambridge University Press. https://doi.org/10.1017/ CB09780511762727

Vanhanen, T. (2003). Democratization: A Comparative Analysis of 170 Countries. Routledge, New York. https: //doi.org/10.4324/9780203614501

Wang, X. (2002). Assessing administrative accountability. American Review of Public Administration, 32, 350-370. https://doi.org/10.1177/0275074002032003005

Warren, M. (2014). Accountability and democracy. In Bovens, M., Goodin, R. E. \& Schillemans, T. (Eds.), The Oxford Handbook of Public Accountability. Oxford: Oxford University Press. https://doi.org/10.1093/oxfordhb/ 9780199641253.013.0018

Wooldridge, J. M. (2010). Econometric analysis of cross section and panel data. Cambridge: The MIT Press. ISBN: 9780262232586 